\title{
ESCAIDE 2010 - an opportunity for sharing knowledge, building capacity and strengthening networks
}

J Giesecke (johan.giesecke@ecdc.europa.eu) ${ }^{1,2}$

1. European Centre for Disease Prevention and Control, Stockholm, Sweden

2. Chairman of the ESCAIDE Scientific Committee

Citation style for this article:

Giesecke J. ESCAIDE 2010 - an opportunity for sharing knowledge, building capacity and strengthening networks. Euro Surveill. 2010;15(35):pii=19650. Available online: http://www.eurosurveillance.org/ViewArticle.aspx?Articleld $=19650$

Article published on 2 September 2010

Between 11 and 13 November 2010 the European Centre for Disease Prevention and Control (ECDC) invites researchers to its fourth annual ESCAIDE conference in Lisbon. ESCAIDE is short for the "European Scientific Conference on Applied Infectious Disease Epidemiology", and this year's edition - just like the previous ones - has a dual aim: first, to provide a forum where exchange of knowledge in epidemiology, microbiology and other related fields is applied in support of prevention and control of infectious diseases. Second, to give the coming generation of European public health scientists within the European Programme for Intervention Epidemiology Training (EPIET), the European Public Health Microbiology Training Programme (EUPHEM) and national field epidemiology training programmes (FETP) an opportunity to present their work [1-2].

The past ESCAIDEs covered a wide range of speakers and subjects. In this issue of Eurosurveillance an article by Faber et al. highlights that physicians may misinterpret patients' expectations to be prescribed antibiotics. It demonstrates that most respondents from a general population sample either do not expect to receive antibiotics for a common cold or would follow the advice of their doctor. The paper, based on a presentation at ESCAIDE, was among the abstracts submitted for the conference that scored highest in the peer-review. It was therefore invited for submission by the editorial team [ref paper]. It serves as a good example of the high quality of contributions at the conference where in many cases the quality of presentations by the young EPIET fellows matched that of their more experienced peers. We are looking forward to this year's ESCAIDE which will provide a new batch of excellent scientific presentations of infectious disease workers from across the European Union and beyond. The call for late breakers for ESCAIDE 2010 opens on 3 September [3].

EUPHEM is the most recent member of the family of training activities funded through the ECDC. It was launched in 2008 as a project within the European Network for Diagnostics of Imported Viral Diseases Collaborative Laboratory Response Network [4], and aims at developing a European network of public health microbiologists to strengthen communicable disease surveillance and control. This is achieved by creating an integrated laboratory - field epidemiology network for outbreak detection, investigation and response. During the 2010 ESCAIDE, the first two fellows who have been the front runners for what will hopefully evolve to be the EPIET fellows' counterpart in the laboratory sphere will receive their diploma.

When he announced ESCAIDE earlier this year, Marc Sprenger, the ECDC Director, stated that "ESCAIDE helps to build and strengthen professional links across the public health community in Europe. It is here that ECDC and its partners can start to build the multi-disciplinary, multi-country approaches needed to strengthen Europe's defences against infectious diseases." Together with EPIET, EUPHEM and the national FETP's ESCAIDE nurtures networks, brokers knowledge sharing, supports European collaboration in public health, and brings new scientists to the fore. This will help create a better prepared and healthier Europe.

Members of the ESCAIDE scientific committee are: Andrea Ammon, ECDC, Arnold Bosman, ECDC, Viviane Bremer, ECDC/EPIET, José Luis Castanheira, Portuguese FETP, Johan Giesecke, ECDC (chair), Aftab Jasir, ECDC, Marion Koopmans, European Society for Clinical Virology, Davide Manissero, ECDC, Lorenzo Pezzoli, EPIET Alumni Network, Fernando Simon Soria, Spanish FETP, Ines Steffens, ECDC, Howard Needham, ECDC, Panayotis Tassios, European Society of Clinical Microbiology and Infectious Diseases.

References

1. Krause G, Aavitsland P, Alpers K, Barrasa A, Bremer V, Helynck B, Perra A. Differences and Commonalities of National Field Epidemiology Training Programmes in Europe. Euro Surveill. 2009;14(43):pii=19378. Available online: http://www. eurosurveillance.org/ViewArticle.aspx?Articleld=19378

2. Bosman A, Schimmer B, Coulombier D. Contribution of EPIET to public health workforce in the EU, 1995-2008. Euro Surveill. 2009;14(43):pii=19381. Available online: http://www. eurosurveillance.org/ViewArticle.aspx?Articleld=19381

3. Eurosurveillance editorial team. ESCAIDE 2010 - call for late breakers. Euro Surveill. 2010;15(35):pii=19653. Available from: http://www.eurosurveillance.org/ViewArticle. aspx?Articleld $=19653$

4. European Network for Diagnostics of "Imported" Viral Diseases (ENIVD). [Internet]. Berlin, Germany. Available from: http:// www.enivd.de/index.htm 